\title{
PENGGUNAAN GPS UNTUK MENDETEKSI PENYEBARAN PENYAKIT TUNGRO PADA DUA MUSIM TANAM PADI DI KECAMATAN POCO RANAKA TIMUR KABUPATEN MANGGARAI TIMUR PROPINSI NUSA TENGGARA TIMUR
}

\author{
Rulianus Boskosar dan Sri Wahyuni \\ Program Studi Agroteknologi Fakultas Pertanian Universitas Flores, Jln. Samratulangi \\ XX -Paupire, Kabupaten Ende, Propinsi Nusa Tenggara Timur \\ sriwahyuni4611@gmail.com
}

\begin{abstract}
Activity of vegetable pesticides formulation in half lifestyle parmarion martens (gastropoda: ariophantidae). This study aims to determine the spread of Tungro disease in the Poco Ranaka Timur District, East Manggarai Regency, and how the development of Tungro disease in each location attacked. Data were analyzed descriptively and based on direct observations obtained in the field. Observation parameters in the form of the presence and development of Tungro disease from each sample location. In the two rice growing seasons by counting the number of clumps attacked in each sample location. The results of the study at nine sample locations showed an increase in the spread of Tungro disease from the first planting season to the second planting season by an average of $27.29 \%$. The highest growth in the range of Tungro disease occurring at the fifth sample location by $90.87 \%$. The lowest at the sample location ninth by $9.09 \%$.
\end{abstract}

Keywords: Rice, Spread, Tungro Disease,

\section{PENDAHULUAN}

Padi (oryza sativa L) merupakan tanaman pangan paling penting bagi masyarakat Indonesia oleh sebab itu kualitas dan produksinya harus ditingkatkan. Produksi padi di Indonesia belum memenuhi kebutuhan dalam negeri, menurut data statistik nasional, total produksi tanaman padi nasional tahun 2015, sebanyak 75,36 juta ton, sementara kebutuhan padi dalam satu tahun penduduk Indonesia sebanyak juta ton 287,09 juta ton (BPS Nasional, 2018). Manggarai timur merupakan salah satu penghasil padi terbesar di pulau Flores dengan produktivitas padi tahun 2017 sebesar 3,91 ton/ha (BPS Manggarai Timur, 2018). Produksi tersebut belum memenuhi kebutuhan masyarakat di duga salah satu penyebabnya yaitu adanya serangan penyakit tungro. 
Penyakit tungro disebabakan oleh dua jenis virus yang berbentuk batang (Baciliform, Rice Tungro Baciliform Virus; RTBV) dan bulat (Spherical,Rice Tungro Spherical Virus; RTSV), dan ditularkan oleh wereng hijau Nephotettix virescens Distant (Hibino dan Cabunagan,1986). Hubungan virus $\mathrm{S}$ dan B sangat unik. Gejala penyakit akan jelas terlihat jika kedua partikel menginfeksi tanaman dan virus B hanya bisa ditularkan oleh vektor yang sebelumnya telah mengakuisisi virus S (Hibino dkk.,1978). Padi yang terkena penyakit tungro terhambat pertumbuhannya dan warna daunnya berubah mulai hijau ke kuning hingga merah jambu. Gejala ini dipengaruhi oleh jenis padi, lingkungan,umur tanaman, dan strain virus. Perubahan warna mulai dari ujung daun dan meluas kebagian pangkal daun. Daun muda tampak belang, sedangkan daun tua mempunyai bercak- bercak coklat karat dengan ukuran yang bervariasi (Haryono semangun,2008). Pada intensitas serangan ringan kehilangan hasil diperkirakan mencapai $15 \%$, intensitas serangan sedang sekitar $35 \%$ dan intensitas serangan berat lebih dari 59\%. Apabila kehilangan hasil mencapai $79 \%$ ke atas maka daerah serangan dinyatakan sebagai puso. (Wasiati,2007).

Kabupaten Manggarai Timur yang memiliki luas areal sawah mencapai 14,949 ha, karena areal sawah yang luas maka sulit untuk mengontrol penyebaran penyakit tungro, salah satu cara untuk mempermudah pemantauan penyebaran penyakit tungro adalah melakukan teknik pemetaan dengan menggunakan teknologi GPS (Global Positioning System) salah satunya di bidang pertanian. Pemetaaan menggunakan GPS telah banyak diterapkan mulai dari membuat peta lahan yang akan di olah, pemetaan hasil perubahan lahan, untuk mengetahui luas lahan yang di garap, memudahkan untuk menentukan lokasi lahan dan Pengambilan sampel tanah di ambil pada lapisan atas pada kedalaman top soil 0-20 cm, 20-40 $\mathrm{cm}$ dan dilakukan pereklaman titik koordinat dengan menggunakan GPS (Global Positioning System).Penggunaan GPS cukup mudah yaitu dengan menentukan letak latitude, longitudedan altitude dari daerah yang akan dibuat pemetaan. Kemudian data-data pengukuran dimasukan menggunakan google earth, untuk memperoleh peta 3D 
(tigadimensi).Hasil dari citra penyebaran penyakit tungro dengan menggunakan metode ini dapat di jadikan acuan dalam memperbaiki areal atau lokasi luas sebaran penyakit tungro untuk beberapa musim berikutnya.

\section{METODE PENELITIAN}

\section{Tempat dan Waktu}

Penelitian dilakasanakan di Kecamatan Poco Ranaka Timur Kabupaten Kabupaten Manggarai Timur, dengan luas sawah mencapai 3.330 ha (BPPS Manggarai Timur, 2018). Penelitian dilakukan pada musim tanam pertama pada bulan Februari dan musim tanam kedua pada bulan Juni.

\section{Alat dan Bahan Penelitian}

Alat utama yang digunakan dalam penelitian ini seperti GPS, bahan yang di gunakan dalam penelitian ini adalah alat tulis, tabel isian titik kordinat dan patokan.

\section{Tahap Penelitian}

1. Persiapan : melakukan survei lokasi berdasarkan gejala serangan, luas serangan dan topografi

2. Perencanaan jalur : menentukan patokan dan jumlah titik sampel melalui latitude, longitude dan altitude untuk mendapatkan titik kordinat lokasi penelitian.

3. Pemetaan atau penentuan titik koordinat

Pemetaan atau penentuantitik
koordinat yang dilakukan untuk
mendapatkan data areal penelitian di
lakukan.

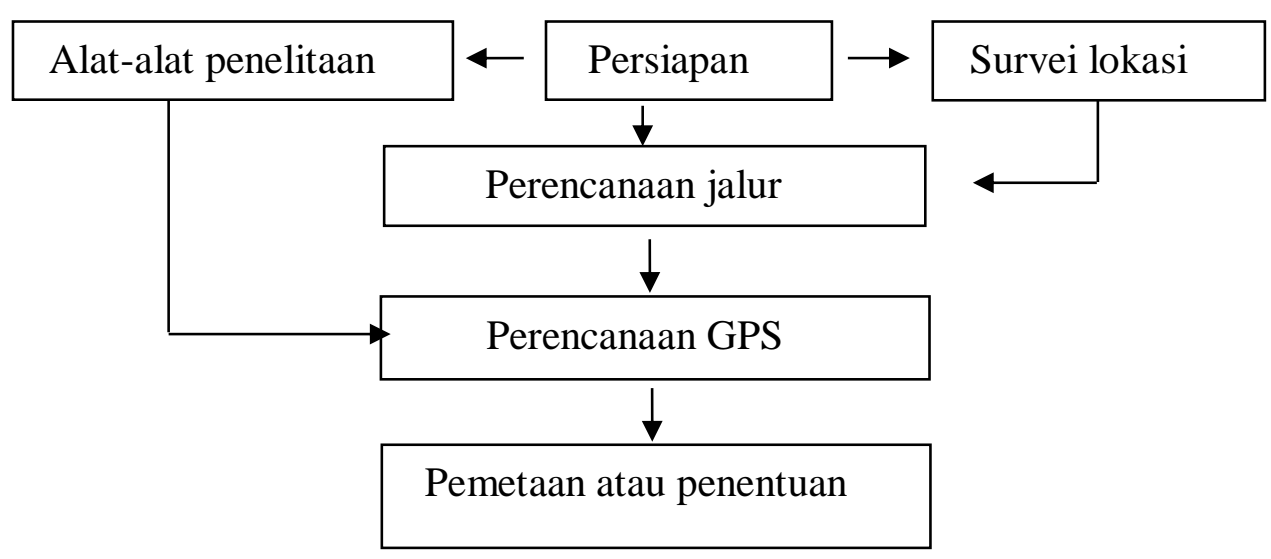

Gambar 1. Alur Tahap Penelitian 



\subsection{Variabel pengamatan.}

1. Menetukan titik koordinat dan jumlah titik koordinat.

Menentukan titik koordinat di lokasi yang terserang penyakit tungro supaya dapat mengetahui latitude, longitudedan altitude.Mengitung jumlah titik koordinat berdasarkan gejala atau serangan yang di sebabkan penyakit tungro pada areal atau lokasi yang terserang penyakit tungro.

2. Jumlah rumpun yang terserang. Rumpun yang di hitung yaitu rumpun yang terserang penyakit tungro pada musim tanam pertama dan musim tanam ke dua.

\subsection{Luaran Penelitian}

Luaran penelitian ini adalah penyebaran penyakit tungro pada 2 musim tanam di Kabupataen Manggarai Timur, tepatnya di Kecamatan Poco Ranaka Timur.

\subsection{Analisis Data}

Data analisis yang digunakan dalam penelitian ini adalah analisis deskriptif kuantitatif yang didasarkan hasil observasi langsung di lapangan.

\section{HASIL DAN PEMBAHASAN}

\subsection{Peta Penyebaran Penyakit Tungro} di Kecamatan Poco Ranaka Timur
Hasil pengamatan memperlihatkan penyakit tungro telah menyebar pada sembilan (9) lokasi di Kecamatan Poco Ranaka Timur dan ternyata mengalami peningkatan jumlah tanaman yang terserang sebesar 27,29\%.

Peta di bawah ini menunjukan lokasi sasaran penelitian rentan terhadap penyebaran penyakit tungro, dikarenakan ketersediaan sumber inokulasi atau tanaman terserang dimana pola tanam yang diterapkan sepanjang tahun adalah monokultur padi. Kondisi ini memungkinkan vektor penular (wereng hijau) akan selalu ada di pertanaman. Fenomena tersebut di perkuat oleh Tiongco et al (1993)yang menyatakan bahwa fluktuasi insidensi tungro berkolerasi positif dengan fluktuasi kepadatan populasi vektor apabila tersedia sumber inokulum.Selain tidak terputusnya siklus hidup wereng hijau, kondisi lain yang memperparah terjadinya perluasan area penyebaran penyakit tungro adalah siklus hidup wereng hujau yang pendek dengan kemampuan makan yang cepat sehingga mempercepat terjadinya penyebaran virus tungro. Hal ini di perkuat oleh hasil penelitianRivera \& $\mathrm{Ou}$ (1965) yang mejelaskan bahwa rentang 
AGRICA, Vol. 12 No. 1 (2019)

waktu periode makan akuisisi wereng hijau untuk mendapatkan virus dari tanaman sakit antara 5-30 menit, sedangkan rentang waktu makan inokulasi untuk menularkan virus yang didapat antara 7-30 menit (Ling, 1968).
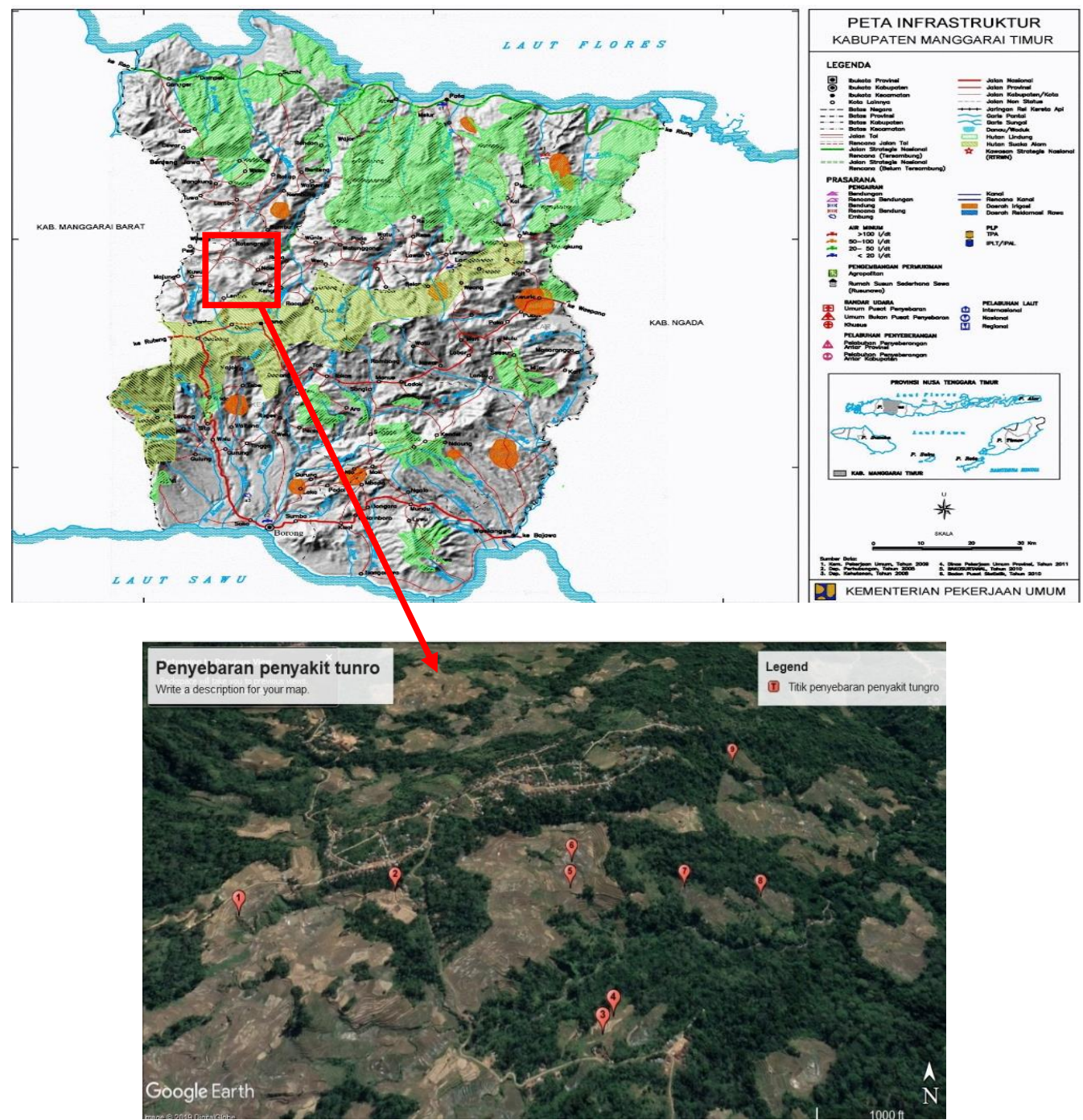

Gambar 2. Lokasi Terserang Penyakit Tungro.

Virus tidak memperlukan periode inokulasi dalam tubuh vektor yang berarti virus tungro tidak membutuhakan waktu yang panjang untuk proses beradaptasi dengan vektor penular. Wereng hijau N.
Virescens dapat langsung menularkan virus tungro sesaat setelah proses akuisisi, dengan masa retensi maksimum kurang dari satu minggu (Ling, 1972). Peta lokasi penyebaran penyakit tungro di Kecamatan 
Boskosar : Penggunaan GPS untuk mendeteksi penyebaran penyakit tungro

Poco Ranaka Timur disajikan pada Kecamatan Poco Ranaka Timur, Gambar 2. Secara jelas latitude, longitude, Kabupaten Manggari Timur disajikan dan altitude sebaran penyakit tungro di dalam Tabel 1 berikut :

Tabel 1. Sebaran Penyakit Tungro di Kecamatan Poco Ranaka Timur.

\begin{tabular}{cccc}
\hline No. Sampel & Latitude & Longitude & Altitude \\
\hline 1 & $8^{0} 33^{\prime} 1,93^{\prime \prime} \mathrm{S}$ & $120^{0} 35^{\prime} 45,67^{\prime \prime} \mathrm{E}$ & $1021 \mathrm{~m}$ \\
2 & $8^{0} 32^{\prime} 59,3^{\prime \prime} \mathrm{S}$ & $120^{0} 35^{\prime} 57,97^{\prime \prime} \mathrm{E}$ & $1023 \mathrm{~m}$ \\
3 & $8^{0} 33^{\prime} 11,29^{\prime \prime} \mathrm{S}$ & $120^{0} 36^{\prime} 14,96^{\prime \prime} \mathrm{E}$ & $993 \mathrm{~m}$ \\
4 & $8^{0} 33^{\prime} 9,73^{\prime \prime} \mathrm{S}$ & $120^{0} 36^{\prime} 15,87^{\prime \prime} \mathrm{E}$ & $191 \mathrm{~m}$ \\
5 & $8^{0} 32^{\prime} 57,53^{\prime \prime} \mathrm{S}$ & $120^{0} 36^{\prime} 12,79^{\prime \prime} \mathrm{E}$ & $980 \mathrm{~m}$ \\
6 & $8^{0} 32^{\prime} 54,75^{\prime} \mathrm{S}$ & $12036^{\prime} 12,96^{\prime \prime} \mathrm{E}$ & $956 \mathrm{~m}$ \\
7 & $8^{0} 32^{\prime} 56,54^{\prime \prime} \mathrm{S}$ & $120^{0} 36^{\prime} 23,09^{\prime \prime} \mathrm{E}$ & $906 \mathrm{~m}$ \\
8 & $8^{0} 32^{\prime} 56,57^{\prime \prime} \mathrm{S}$ & $120^{0} 36^{\prime} 30,26^{\prime \prime} \mathrm{E}$ & $890 \mathrm{~m}$ \\
9 & $8^{0} 32^{\prime} 40,62^{\prime \prime} \mathrm{S}$ & $120^{0} 36^{\prime} 30,07^{\prime \prime} \mathrm{E}$ & $915 \mathrm{~m}$ \\
\hline
\end{tabular}

\subsection{Keberadaan Penyakit Tungro}

Hasil pengamatan selama 5 bulan di setiap lokasi terserang penyakit tungrodengan gejala berupa daun berwarna kuning dan terlambat berbunga. Kondisi yang demikian dapat merugikan petani karena kerusakan tanaman padiakibat penyakit tungro,anakan berkurang, menghambat proses pembungaan, memperlambat proses fotosintesis dan kerdil. Tanaman sakit terlambat membentuk bunga. Malai kecil dan tidak sama sekali keluar dari upih daun, kebanyakan bijinya hampa atau terisi sebagian dan sering mempunyai becak-bercak coklat tua. Tanaman kurang membentuk akar, tanaman sakit cenderung lebih rentan terhadap bercak coklat (Drechslera oryzae) dan bercak coklat sempit (Cercospora janseana) (Anon., 1971 dalam Haryono Semangu). Menurut Soetarto dkk. (2001), rerata luas serangan tungro setiap tahun mencapai 12.000 ha, bahkan pada saat outbreak luas serangan di satu propinsi saja bisa menyamai atau mencapai beberapa kali lipat rerata luas serangan tahunan nasional.

Keberadaan penyakit tungro di Kecamatan Poco Ranaka Timur sudah di ketahui oleh para petani namun belum menemukan solusi atau cara untuk mengendalikan penyakit tungro tersebut. 
Menurut laporan dari para petani populasi tungro meningkat pada akir musim kemarau dan awal musim hujan.Hasil pengamatan menujukan bahwa populasi wereng hijau pada musim kemarau lebih rendah dari pada musim hujan (Carino 1980). Pola flukltuasi populasi wereng hijau dan keberadaan tungro di kebun percobaan lokatungro lanrang,sulawesi selatan menunjukan adanya dua puncak populasi wereng hijau yang terjadi dalam satu tahun dan kepadatan polulasi pada musim kemerau (Ahir Agustus) lebih tinggi dari pada musim hujan (April). Faktor iklim terutama suhu berpengaruh terhadap daur hidup wereng hujau, pemerolehan virus dan penularan virus (Hasanudin, 1991).

Tabel 2. Jumlah rumpun yang terserang penyakit tungro di Kecamatan Poco Ranaka Timur pada 2 musim tanam.

\begin{tabular}{ccc}
\hline No sampel & Jumlah rumpun musim 1 & Jumlah rumpun musim 2 \\
\hline 1 & 56 rumpun & 72 rumpun \\
2 & 15 rumpun & 32 rumpun \\
3 & 80 rumpun & 143 rumpun \\
4 & 24 rumpun & 37 rumpun \\
5 & 11 rumpun & 230 rumpun \\
6 & 131 rumpun & 87 rumpun \\
7 & 65 rumpun & 78 rumpun \\
8 & 38 rumpun & 62 rumpun \\
9 & 42 rumpun & 65 rumpun \\
\hline
\end{tabular}

Pada Tabel 2 dapat di lihatjumlah yang paling banyak terserang pada dua musim tanam terdapat pada titik koordinat yang kelimayaitu $90,87 \%$ dan yang terendah terdapat pada titik kordinat yang ketujuh yaitu 9,09\%.

Seperti yang di tunjukan pada Gambar 3 bahwa pada titik kelima populasi tungro pada dua musim tanam meningkat sampai $90,87 \%$, peningkatan ini terjadi karena vektor yangkemampuan makan cepat sehingga mempercepat terjadi penyebaran penyakit tungro. Populasi penyebaran penyakit tungro yang paling rendah terdapat pada titik ketujuh yaitu 20,18\%. Pada titik keenam musim tanam pertama petani mengendalikan dengan memusnakan rumpun yang 
terserang dengan cara mencabut dan di bakar, sehingga wereng hijau yang terdapat pada lokasi ini tidak lagi mempunyai sumber inokulasi (tanaman terserang) cara ini membuahkan hasil karena populasi tungro pada musim tanam ke dua pada lokasi ini menurun. Hal ini di perkuat oleh hasil penelitian Anomim (2006) yang menyatakan bahwa upayaupaya yang di lakukan petani untuk mengantisipasi terhadap peningkatan serangan virus tungro yaitu berupa pengendalian kuaritif. Di Jawa Timur dalam tahun 2006 seluas 4.193,87 ha dengan perincian: pemusnahan seluas 221,85 ha, aplikasi pestisida seluas $3.335,77$ ha dan cara lain seluas 616,25 ha. Menurut Mutmainna (2012) untuk mengendalikan penyakit tungro perlu di lakukan yang pertama dengan menggunakan varietas tahan seperti Tukad Unda, Tukad Balian, Tkad Petanu, Bondoyudo dan Kalimas merupakan cara terbaik untuk mengendalikan tungro. Rotasi varietas penting untuk mengurangi gangguan ketahanan. Mencabut dan bakar tanaman yang sakit, ini di lakukan kecuali bila serangan tungro sudah menyeluruh. Bila serangan sudah tinggi maka mungkin ada tanaman yang terinfeksi tapi kelihatan sehat. Yang ketiga waktu tanam padi saat populasi wereng hijau tungro rendah. Yang keempat tanaman serempak, upaya petani tanam serempak. Ini mungurangi penyebaran tungro dari satu lahan ke lahan lainnya karena stadium tumbuh yang relatif seragam.

penyebaran penyakit tungro inidapat merugikan petani, karena semakin luas penyebaran penyakit tungro maka semakin luas juga kerusakan tanaman padi. Hal ini membawa dapak buruk bagi penghasilan para petani akan semakin menurun.

Di setiap lokasi terserang penyakit tungro peneliti menemukan vektor (penular) yaitu wereng hijau, selain itu petani tidak menggunakan pola tanam yang serempak. Penanaman yang tidak serempak akan menjamin ketersediaan inang dalam rentang waktu yang panjangbagi perkembangan virus tungro, sehingga memungkinkan wereng hijau berkembang karena adanya sumber inokulasi (tanaman terserang).

Tinggi rendahnya intesitas penyakit tungro di tentukan oleh beberapa faktor, diantaranya ketersediaan sumber inokulasi, adanya vektor, adanya tanaman 
peka dan kondisi lingkungan yang memungkinkan (Suzuki dkk. 1992).

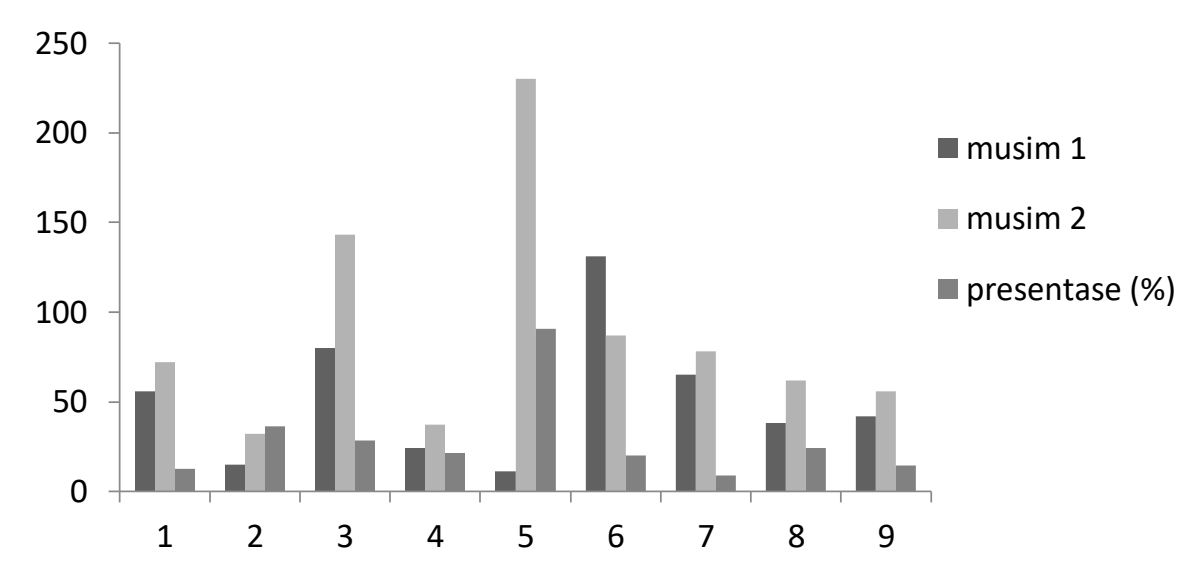

Gambar 3. Peningkatan presentase penyebaran penyakit tungro pada dua musim tanam.

\section{SIMPULAN}

Penyebaran penyakit tungro telahmenyebar pada sembilan lokasi di Kecamatan Poco Ranaka Timur dan terjadi peningkatan penyebaran penyakit tungro sebesar $27,29 \%$ dari musim tanam pertama ke musim tanam kedua.

\section{UCAPAN TERIMAKASIH}

Terimakasih yang setinggitingginya penulis sampaikan kepada orang tua, lembaga pendidikan Program Studi Agroteknologi, Universitas Flores dan aparat desa sekacamatan Poco Ranaka yang telah membantu kelancaran proses penyelesaian penelitian ini.

\section{DAFTAR PUSTAKA}

Anmonim, (2006), Departemen Pertanian. Pusat Data Informasi Pertanian. http//www. deptan. go. id (diakses 2 oktober 2015).

Badan Pusat Statistik Kabupaten Manggarai Timur 2018, produktifitas padi tahun 2015, tahun 2016 dan tahun 2017.

Badan Pusat Statistik Nasional 2018, produksi padi tahun 2015 dan tahun 2016.

Carino, F.O. 1980. Role of natural enemies in population suppression and pest management of the green leat hopper. UPLB. MS. Thesis.

Haryono Semangun. 2008, penyakitpenyakit tanaman pangan di indonesia, gadjah mada university press, yogyakarta. 
Boskosar : Penggunaan GPS untuk mendeteksi penyebaran penyakit tungro

Hasanuddin, A. 1991. Pengaruh faktor iklim terhadap aktivitas serangga wereng hijau (Nephottetikx Virescens Distant) dan dan serangan penyakit tungro. Prosiding Simp. Meteorologi Pertanian III. Malang, 20-22 agustus 1991.

Hibino, H. 1978. Asosiasi jenis deret partikel virus dengan penyakit hambang beras di Indonesia. Phytopatology 68 : 1266-1268.

Hibino, H. dan R. C. Cabunaga. 1986. Rice tungro terkait virus dan hubungannya dengan tanaman inang dan wereng vector. Trop. Agr. Res. Ser. 19 ; 173-182.

Imam, B dan Haris, I, 2011. Penggunaan global positioning system (GPS) untuk pembuatan peta situasi pada Sub Das jeratun seluna, BBIHP, Bogor.

Jurnal perlindungan tanaman indinesia, vol. 3, no. 1 : 23-31, 1997, status penyebaran penyakit tungro di jawa barat.

Ling KC. 1968. Mechanism of tungro resistance in rice variety pankhari 203. Philipphine phytopatol 4: 2138.

Mutmainna, 2012. Penyakit tungro pada tanaman padi dan cara pengendaliannya.

Ling KC. 1972. Rice virus desease. International Rice Research Institute. Los Banos, Philippines.
Panindya, A, 2014. Global positioning system (GPS). http//eprints.polsri.ac.id.

Pracaya. 2007, Hama dan penyakit tanaman, jakarta, penebar swadaya, 2011.

Prihandito, A. 1988. Proyeksi peta, yogyakarta. Kanisius.

Pusat pengolahan data,. 2015. Survy dan pemetaan menggunakan GPS balai pemetaan temstik dan prasarana dasar. Jakarta.

Rivera CT, Ou SH. 1965. Leafhopper transmission of "tungro" disease of rice. Plant. Dis. Rep.49:127131.

Sartono Joko dan I. Indriyati Wibisono. 2007,Hama dan penyakiy tanaman pangan. Yogyakarta.

Sutarto, A., Jasis, W.W.G. Subroto, M. Siswanto, \& E. Sudyanto. 2001. Sistem peramalan dan penendalian OPT dalam mendukung sistem produksi padi berkelanjutan. Dalam Implementasi Kebijakan Stategi Untuk Meningkatkan Produksi Padi Berwawasan Agribisnis dan Lingkungan. las eds. Puslitbang Tanaman Pangan.

Suzuki,Y., I.G.N.Astika, I.K.R.Widrawan, I.G.N.Gede, I.N.Raga, and Soeroto.1992. Rice tungro disease transmitted by green leafhoppers: itsepidemiology and forecasting. JARQ26:98-104 
AGRICA, Vol. 12 No. 1 (2019)

Tamba, Ryanto.2012 virus tungro.http://r yantotamba.blogspot.com/2012/01 /virus tungro.html. diakses 26desember 2012.

Tassim, B; 2011. Panduan pengukuran areal perkebunan menggunakan GPS pusat data dan sistem informasi pertanian. Kementrian pertanian. Jakarta.

Tiongco, E.R.,R.C. Cabungan, Z.M. Flores, H. Hibino, \& H.Koganezawa. 1993. Serological Monitoring of Rice Tungro Disease Development in the Field : its Implication in Disiase Management. Plant disease 77: 877-882.

Wasiati, A 2007. Buku pegangan bagi pengamathama penyakitpengendalian organismpengganggu tanaman (PHP-POPT).Direktor perlindungan tanaman pangan. Jakarta. 